Chair for Management Sciences and Energy Economics University of Duisburg-Essen

EWL Working Paper No. 01/11

\title{
The Cost of Equity of Network Operators - Empirical Evidence and Regulatory Practice by
} Stephan Schaeffler and Christoph Weber 


\title{
The Cost of Equity of Network Operators - Empirical Evidence and Regulatory Practice
}

\author{
Stephan Schaeffler and Christoph Weber
}

\begin{abstract}
In many European countries, the deregulation of energy markets leading to the introduction of unbundling and incentive regulation for utilities firms has made the task of setting an adequate cost of equity more difficult. Firstly, Legal Unbundling led to the creation of many legally independent network operators that have to be regulated separately, excluding the generation or sales activities of mother firms. Identifying adequate costs of capital is thereby complicated by the fact that only very few network operators are traded on stock exchanges. Secondly, the increased pressure through incentive regulation schemes has reinforced the importance of setting the equity return adequately. The approaches chosen by regulatory agencies have often been accompanied by heavy criticism regarding methodology and empirical data sets used. In this context the question arises, how regulators set equity returns for network operators and whether the methodologies applied are in line with state-of-the-art capital market models.

This paper therefore starts by providing an overview on empirical results, reviewing major published studies of betas and equity returns regarding utilities and network operators. This research helps to identify and discuss the most important drivers of capital costs which is an indispensable groundwork for determining adequate betas. Additionally, an overview of the current practice of regulatory equity return setting is provided. These results are then compared to an empirical analysis based on a recent data set with more than 20 network operators. Based on this data set the required equity returns according to different methodologies (CAPM, Fama-French-TFM, Ross-APT) are computed. This provides evidence that regulatory practice in Europe and Australia ignores the Fama-French-TFM or the APT, even though notably the Fama-French TFM shows the potential to provide improved estimates of required equity returns. The paper concludes by providing a suggestion on how to put the FF TFM into practice accounting for the size of non-stock listed network operators.
\end{abstract}

Keywords: Network operator, cost of capital, asset pricing models, regulation, cost of equity JEL-Classification: G31, G38, L9

STEPHAN SCHAEFFLER

Horváth \& Partners Management Consultants

(Ganghoferstr. 39, 80339 München)

++49 - (0)89 / 544625-15

www.horvath-partners.de

sschaeffler@horvath-partners.com

\section{CHRISTOPH WEBER}

Chair for Management Science and Energy Economics, Chairman

University of Duisburg-Essen

(Universitätsstr. 11, 45117 Essen)

++49 - (0)2 01 / 183-2966

www.ewl.wiwi.uni-due.de

The authors are sorely responsible for the contents which do not necessarily represent the opinion of the Chair for Management and Energy Economics. 


\section{Introduction}

In many European countries, the deregulation of energy markets leading to the introduction of unbundling and incentive regulation for utilities firms has made the task of setting an adequate cost of equity more difficult. Firstly, Legal Unbundling has led to the creation of many legally independent network operators that have to be regulated separately, excluding the generation or sales activities of mother firms. Identifying adequate costs of capital is thereby complicated by the fact that only very few network operators are traded on stock exchanges. Secondly, the increased pressure through incentive regulation schemes has reinforced the importance of setting the equity return adequately. The approaches regulatory agencies have taken have often been accompanied by heavy criticism regarding methodology and empirical data used. In this context the question arises, how regulators set equity returns for network operators and whether the methodologies applied are in line with state-of-the-art capital market models..

The standard model for determining capital costs still is the Capital Asset Pricing Model (CAPM), developed by Sharpe (1964), Lintner (1965) and Mossin (1966). An application of the CAPM-concept or comparable multi-factor concepts such as the three-factor-model (TFM) presented in Fama and French (1992) or the Arbitrage Pricing Theory (APT) by Ross (1976) require stock data of comparable firms in order to compute the systematic risk(s) of a business. ${ }^{1}$ The process of Unbundling has led to a legal separation between sales and generations activities on the one hand and network operations on the other hand each with own systematic risk profiles. Facing the challenge of data availability regarding network operators, regulators have to decide some crucial points: Use the CAPM or use other valuation models including for instance size and distress risk? Include integrated companies in the company sample? Differentiate between branches (electricity or gas network operation) in setting returns? How to handle leverage? ${ }^{2}$

These considerations are essential and tightly linked to the specific risks network operators face in opposition to the risk profile of integrated companies. Generation risks include the demand side, market prices and hedging activities (oil, coal, gas, $\mathrm{CO}^{2}$ ) and the investment risk in a certain technology. Sales risk is mainly driven by demand level, competition intensity and procurement risks. Network operations as a natural monopoly are characterized by a different risk profile: The demand risk is fairly reduced to the lack of competition; however regulation does have a major impact on business risk. In a price cap regime without adequate compensation mechanism, the network operator incurs a demand risk if demand temporarily decreases due to for instance a significant conjecture impact. In a revenue cap regime, this kind of systematic risk does not exist.

One aim of this paper is to summarize major empirical results obtained by researchers with regard to the discussed questions. Due to the fact that Unbundling is a more recent occurrence, results from studies based on data from integrated companies will also be taken into account if meaningful. Due to the focus on the discussion of risk factors, we will neglect some parts of the methodological discussion. Dobbs (2008) for instance states that one-point estimates are not adequate to set WACCs in a regulatory process. He thus presents a Monte Carlo-simulation based approach to compute a distribution for the WACC. Literature on utilities' cost of equity is vast: A branch of research is dedicated to computing utilities' equity returns based on different methodological approaches. Some authors have been focusing on the question, how finance theory may be applied to regulation with regards to the problem of beta instability. A third branch of research has focused on the question, if and how regulation influences systematic risk. This research is based on a hypothesis by Peltzman (1976) who assumes that regulators buffer shocks and thus decrease systematic risk. One aim of this paper consequently is to give a more detailed overview of results obtained in the field of empirical

\footnotetext{
1 The three-factor-model (TFM) presented in Fama and French (1992) additionally incorporates size and valuation effects. An alternative to the CAPM based on a fundamentally different approach is the Arbitrage Pricing Theory (APT) by Ross (1976). The expected return for a stock depends linearly on a set of factors that may for instance be macroeconomic such as interest yield, GDP growth or default risk premium.

${ }^{2}$ Leverage is an important driver of risk at a firm and industry-specific level. As the systematic risk beta can only be measured in its leveraged form ('equity beta'), several techniques exist to unlever it obtaining an 'asset beta', cf. Pratt and Grabowski (2008, pp. 143-150). After unlevering, which results in excluding the capital structure risk, only the business risk is reflected in the asset beta. Therefore, in the following sections the influences on systematic risk will be measured using asset betas.
} 
research, the focus being utilities in general and network operators in particular. As such, this paper shall serve as a hub to research papers and give numerous sources for practitioners and researchers. Secondly, this paper will present and discuss the most important drivers of equity returns. Thirdly, as data sources with regard to network operators are limited; this paper will show how regulators handle the equity cost and evaluate these approaches. Fourthly, this paper will present an application of different valuation models to a set of 20 network operators. As such it is the first paper comparing the effectiveness of different equity cost valuation models to a relatively large set of network operators.

The structure of this paper is as follows. The second section gives an overview of literature regarding empirical evidence and discusses the range of results obtained and the major explanatory factors. Section three presents an overview of the approach regulation authorities have taken in more than 20 mostly European countries. In section four, results of an own analysis based on the CAPM, the Fama-French-Three-Factor-Model and the APT are presented. In section 5, an approach of how regulators may use a simplified TFM model with regard to non-listed firms is discussed. The last section concludes.

\section{Empirical Evidence about Utilities' Cost of Capital}

This section is twofold: First, an overview over existing empirical evidence is given. Second, the main drivers of systematic risk are discussed in order to gain insights about the relevance of methodological choices for practical applications of the cost of capital models.

\subsection{Overview on Empirical Evidence}

Empirical work on equity cost of utilities is vast, with the first results already published in the 1960s. Table 1 presents important empirical results obtained by various authors, mostly for integrated utilities as unbundling has gained major importance only during the last decade, e. g. with the unbundling standards set in the European Union in the year 2003. 
Table 1: Comparison of empirical studies' results (interest rates computed to real values)

\begin{tabular}{|c|c|c|c|c|c|c|c|c|c|}
\hline Authors & Data & Years & Model & $\boldsymbol{\beta}_{\mathbf{a}}$ & $\beta_{\mathrm{e}}$ & $\mathbf{r}_{\mathrm{m}}-\mathbf{r}_{\mathbf{f}}$ & $\mathbf{r}_{\mathrm{e}}-\mathbf{r}_{\mathbf{f}}$ & $\mathbf{r}_{\mathrm{f}}$ & $\mathbf{r}_{\mathrm{e}}$ \\
\hline Miller and Modigliani (1966) & 63 US electric utilities & $1954-1957$ & DGM & - & - & - & $3.7 \%$ & $0.8 \%$ & $4.5 \%$ \\
\hline Litzenberger and Rao (1971) & 78 US electric utilities & $1960-1966$ & DGM & - & - & - & $2.2 \%$ & $0.0 \%$ & $2.2 \%$ \\
\hline McDonald (1971) & 102 US electric and gas utilities & $1958-1969$ & DGM & - & - & - & $2.5 \%$ & $1.5 \%$ & $3.9 \%$ \\
\hline Higgins (1974) & 81 US electric utilities & $1960-1968$ & DGM & - & - & - & $2.9 \%$ & $0.0 \%$ & $2.9 \%$ \\
\hline Pettway (1978) & 36 US electric utilities & $1971-1976$ & CAPM & - & 0.50 & - & - & - & - \\
\hline $\begin{array}{l}\text { Hagerman and Ratchford } \\
\text { (1978) }\end{array}$ & $\begin{array}{l}\text { Value Line Investment Survey, } 89 \\
\text { utilities companies, questionnaires }\end{array}$ & 1975 & CAPM & 0.32 & 0.69 & - & $5.4 \%$ & $-0.4 \%$ & $5.0 \%$ \\
\hline Thompson (1979) & 76 US electric utilities & $1958-1976$ & DGM & - & - & - & $7.6 \%$ & $0.7 \%$ & $8.2 \%$ \\
\hline Clarke (1980) & 50 US electric utilities & $1965-1974$ & CAPM & - & 0.62 & - & - & - & - \\
\hline \multirow[t]{2}{*}{ Bower et al. (1984) } & \multirow[t]{2}{*}{77 US electric and 25 US gas utilities } & \multirow[t]{2}{*}{ 1971-1979 } & CAPM & - & 0.68 & $10.9 \%$ & $7.4 \%$ & $-1,7 \%$ & $5.7 \%$ \\
\hline & & & APT & - & - & - & $5.4 \%$ & $-1.0 \%$ & $4.4 \%$ \\
\hline Brigham et al. (1985) & Dow Jones Utilities & $1966-1984$ & DGM & - & - & $5.6 \%$ & $5.1 \%$ & $2.1 \%$ & $7.1 \%$ \\
\hline \multirow[t]{2}{*}{ Conine and Tamarkin (1985) } & \multirow[t]{2}{*}{60 US electric utilities } & \multirow[t]{2}{*}{$1971-1980$} & CAPM & - & \multirow[t]{2}{*}{0.77} & $7.5 \%$ & $5.8 \%$ & $2.1 \%$ & $7.9 \%$ \\
\hline & & & TFM & - & & $7.5 \%$ & $7.2 \%$ & $2.1 \%$ & $9.3 \%$ \\
\hline Norton (1985) & CRSP, 21 regulated companies & 1975 & CAPM & - & 0.63 & - & - & - & - \\
\hline Fraser et al. (1986) & 86 US electric utilities & $1974-1983$ & CAPM & - & 0.35 & - & - & - & - \\
\hline Shome and Smith (1988) & 96 US electric utilities & 1971-1985 & DGM & - & - & - & $3.6 \%$ & $2.1 \%$ & $5.7 \%$ \\
\hline Golec (1990) & 79 US electric utilities & $1969-1983$ & CAPM & - & 0.36 & - & - & - & - \\
\hline Gombola and Kahl (1990) & 61 US electric and 48 US gas utilities & $1967-1981$ & CAPM & - & 0.52 & - & - & - & - \\
\hline Riddick (1993) & $\begin{array}{l}\text { Electric and gas distribution utilities on } \\
\text { CRSP tapes }\end{array}$ & $1965-1986$ & CAPM & - & 0.53 & - & - & - & - \\
\hline Elton et al. (1994) & NYSE, sample of 122 utilities & $1978-1990$ & APT & - & - & - & $6.0 \%$ & $2.6 \%$ & $8.6 \%$ \\
\hline Alexander et al. (1996) & Utilities from more than 15 countries & 1990-1995 & CAPM & 0.50 & - & - & - & - & - \\
\hline \multirow[t]{2}{*}{ Fama and French (1997) } & \multirow[t]{2}{*}{ NYSE, AMEX, NASDAQ } & \multirow[t]{2}{*}{ 1963-1994 } & CAPM & - & 0.66 & $5.2 \%$ & $3.4 \%$ & $1.4 \%$ & $4.8 \%$ \\
\hline & & & TFM & - & - & & $5.4 \%$ & $1.4 \%$ & $6.8 \%$ \\
\hline Cooper and Currie (1999) & LBSRMS, seven water companies & 1994-1999 & CAPM & 0.57 & 0.72 & $9.2 \%$ & $6.6 \%$ & $2.8 \%$ & $9.4 \%$ \\
\hline Buckland and Fraser (2001) & LSE, 10 UK water companies & 1989-1999 & CAPM & 0.60 & 0.76 & - & - & - & - \\
\hline \multirow[t]{2}{*}{ Cragg et al. (2001) } & \multirow{2}{*}{$\begin{array}{l}\text { US and UK electric, gas and pipeline } \\
\text { companies }\end{array}$} & \multirow{2}{*}{ 1990-1999 } & CAPM & - & 0.55 & - & $4.6 \%$ & $2.7 \%$ & $7.3 \%$ \\
\hline & & & APT & - & - & - & $9.8 \%$ & $2.7 \%$ & $12.5 \%$ \\
\hline Miller and Zhang (2003) & $\begin{array}{l}\text { S\&P IFCG China Index, } 12 \text { electric and } \\
3 \text { water utilities }\end{array}$ & 1993-2002 & CAPM & - & 0.97 & $7.9 \%$ & $7.7 \%$ & $2.0 \%$ & $9.7 \%$ \\
\hline \multirow[t]{2}{*}{ Gerke (2003) } & 14 German utilities in CDAX utilities & $1992-2001$ & CAPM & 0.48 & - & $3.6 \%$ & $1.7 \%$ & $4.7 \%$ & $6.4 \%$ \\
\hline & 17 European utilities & $1992-2001$ & CAPM & 0.65 & - & $7.9 \%$ & $5.1 \%$ & $4.7 \%$ & $9.8 \%$ \\
\hline Gray and Officer (2004) & Energy Distribution and Retailing GICS & $1994-2004$ & CAPM & - & 1.02 & - & - & - & - \\
\hline Lally (2005) & 64 US electric and 29 US gas utilities & 1999-2003 & CAPM & 0.30 & 0.75 & - & - & - & - \\
\hline Rocha et al. (2007) & Value Line Investment Survey & $1998-2005$ & CAPM & 0.41 & - & $6.9 \%$ & $5.2 \%$ & $2.8 \%$ & $8.0 \%$ \\
\hline Frontier Economics (2008) & $\begin{array}{l}11 \text { integrated utilities companies, } \\
12 \text { network operators }\end{array}$ & 2006-2007 & CAPM & 0.39 & 0.79 & $3.0 \%$ & $6.6 \%$ & $3.0 \%$ & $6.6 \%$ \\
\hline \multirow[t]{2}{*}{ Kema Consulting (2008) } & 6 European electricity network operator & $2000-2008$ & CAPM & 0.37 & 1.00 & $6.3 \%$ & $6.3 \%$ & $2.7 \%$ & $9.1 \%$ \\
\hline & 4 European gas network operators & $2000-2008$ & CAPM & 0.41 & 1.10 & $6.3 \%$ & $6.9 \%$ & $2.7 \%$ & $9.7 \%$ \\
\hline$P w C$ (2009) & $\begin{array}{l}7 \text { integrated utilities companies, } \\
11 \text { network operators }\end{array}$ & 2004-2009 & CAPM & - & 0.90 & $5.0 \%$ & $4.5 \%$ & $2.5 \%$ & $7.0 \%$ \\
\hline
\end{tabular}

Some adaptations were required to enhance comparability. All nominal values were adjusted for inflation using data from the US Federal Reserve. If the risk-free rate was not published in the paper, T-Bill 3 months average for the analyzed period was taken as proxy. For the later publications regarding Europe and South America, such modifications were not necessary as real values were published. A table with all modifications is available upon request.

Unfortunately, empirical research on required equity returns regarding specifically network operators is scarce with only four studies, the oldest dating from 2004 (Gray and Officer). In earlier studies, authors have often referred to the equity beta while the more recent research focuses on asset betas in order to differentiate between business risks and risks due to the financing structure. 


\subsection{Drivers of Estimated Equity Returns}

In this section, reasons for the obtained differences are discussed. The aim of this work is to identify the relevance of various methodological choices for the empirical results obtained. This is crucial for helping regulators and network operators to apply adequate cost of capital concepts

\section{Valuation Models}

The choice of the cost of equity model has considerable impact. Thompson (1979) discusses the important differences obtained with various dividend growth models notably taken from papers by Miller and Modigliani (1966), McDonald (1971), Litzenberger and Rao (1972) and Higgins (1974). A more recent discussion concerns differences obtained with CAPM and APT on identical data sets. Bower et al. (1984) claim that regulatory authorities should not use the single-factor CAPM-approach but refer to the APT-approach. Conine and Tamarkin (1985) find that using a three-moment CAPM leads to significantly higher capital cost estimates than using the standard CAPM. Elton et al. (1994) find that the difference between valuations based on either CAPM or APT is significant. In another empirical research, Fama and French (1997) find that a difference of about 2\% between CAPM and TFM is common. Cragg et al. (2001) find differences of more than 5\%.

Yet no published empirical research has so far focused on the impact of valuation models in the case of network operators. Section 4 will therefore analyze whether the choice of valuation model has a significant impact on required returns for network industries.

\section{Activities in the value chain: Network operator vs. integrated utility company}

Betas reflect systematic risk. Consequently, integrated utilities should be characterized by different betas than pure distribution or transmission network operators. Unfortunately, most empirical evidence has been founded on data of integrated US electric companies. One interesting first step is consequently to compare pure (either transmission or distribution, or mixed) network companies with integrated companies. We identified four studies that permitted to separate results with regard to the value chain.

Table 2: Differences in beta by value chain activity

\begin{tabular}{lllllll}
\hline \hline Beta values & $\begin{array}{l}\text { Equity beta } \\
\text { Integrated }\end{array}$ & Network & $\boldsymbol{\Delta}$ & $\begin{array}{l}\text { Asset beta } \\
\text { Integrated }\end{array}$ & Network & $\boldsymbol{\Delta}$ \\
\hline \hline Gray and Officer (2004) & 0.87 & 0.65 & 0.22 & 0.45 & 0.36 & 0.09 \\
Frontier Economics (2008) & - & - & - & 0.50 & 0.39 & 0.11 \\
Kema Consulting (2008) & 0.68 & 0.61 & 0.07 & 0.43 & 0.37 & 0.06 \\
PwC (2009) & - & - & - & 0,38 & 0,34 & 0,04 \\
Mean values & 0.74 & 0.63 & 0.15 & 0.44 & 0.37 & 0.08 \\
\hline
\end{tabular}

Frontier Economics (2008) conclude that risks are significantly different for network operators as compared to integrated utilities firms. Table 2 supports this assumption; one can see that betas of integrated utilities are higher than network operator betas. In the available studies, no significant evidence can be found for a difference between pure distribution network operators, pure transmission network operators and mixed forms. One may thus conclude that often liberalized generation and retail activities are characterized by higher systematic risks than the regulated network business.

\section{Branch: Electricity, gas and water}

Table 3 shows beta differences found in studies related to branches. Systematic risks might differ to the lack of generation price risk (water), a more important dependence on economic cycles (electricity demand, price of raw materials such as oil and coal) and transportation risk (gas). These differences are only to very minor degree network specific. ${ }^{3}$ However, results are ambiguous and do not clearly lead to a conclusion that a differentiation between the branches electricity and gas is mandatory. A comparison with water betas is problematic, due to the fact that only two papers were published using UK-data.

\footnotetext{
${ }^{3}$ One possible exception is the competition on the demand side between oil and gas heating leading to additional systematic risk. Another may be that gas demand is more volatile to temperature than electricity.
} 
Table 3: Differences in beta by branch

\begin{tabular}{llll}
\hline \hline Studies & \multicolumn{2}{c}{ Asset Beta } & \\
& Electricity & Gas & Water \\
\hline \hline Alexander et al. (1996) & 0.56 & 0.51 & 0.46 \\
Gray and Officer (2004) & 0.59 & 0.59 & - \\
Lally (2005) & 0.27 & 0.22 & - \\
Frontier Economics (2008) & 0.45 & 0.42 & - \\
Kema Consulting (2008) & 0.37 & 0.41 & - \\
PwC (2009) & 0.41 & 0.33 & 0.31 \\
Mean values & 0.44 & 0.41 & 0.39 \\
\hline
\end{tabular}

Frontier Economics (2008) describe beta differences between electricity and gas utilities of 0.03 comparable to the mean values indicated in Table 4, but find, testing for statistical effects, that differences are insignificant.

\section{Regulation scheme and regulatory events}

One further question of interest is, if regulation itself will increase or decrease systematic risk. The discussion is based on Peltzman's hypothesis (1976) that regulators will buffer shocks. Norton (1985) and Alexander et al. (1996) provide evidence that more regulation will lead to a lower systematic risk. ${ }^{4}$ In the recent environment of many network operators, characterized by unbundling and incentive regulation, it is unclear if this effect still exists in practice. Rammerstorfer ${ }_{5}$ (2009) analytically discusses the link between regulatory regime and the systematic risk. $^{5}$

The regulatory risk for network operators under incentive regulation, such as the nonacceptance of the regulated asset base, stranded investments and effects of network size and age structure are specific to firms and as such not represented in beta. ${ }^{6}$ Consequently, Frontier Economics (2008) find that average asset beta for a network operator under incentive regulation is not significantly different compared to the value of an operator under a cost of service regulation. From these results, different conclusions are possible: Either no real differences exist or these differences are dominated by other effects, such as the rigor of the regulation authority, which obviously may be more important than the regulation regime itself.

\section{Default and distress risk (firm size, book-to-market ratio)}

Banz (1981), Fama and French (1995) and others observed that required equity cost is negatively related to firm size in a systematic way. This may be due to the fact that smaller companies are in general more risky, as bankruptcy is more costly for smaller than for bigger firms, cf. for instance Warner (1977). In a later article, Fama and French (1997) compute equity costs for different industries with interesting though irritating findings. Their threefactor-model indicates important negative signs for the size parameter for energy, utilities and telecom companies while the mean value over all industries is positive. This means that from a cross-industry perspective, smaller firms have higher required equity returns than bigger firms but that somehow for some regulated businesses, this effect is reversed. ${ }^{7}$ Further, they

\footnotetext{
${ }^{4}$ Norton (1985) analyzes the impact of regulation on beta estimates, regulation being characterized by breadth of authority conferred by statues, commission staff and budget size and judicial decisions. He finds that the equity beta of strongly regulated utility firms is about 0.12 lower than that of unregulated firms. Alexander et al. (1996) present 1991 to 1995 data for a large number of companies and countries, discussing the link between the regulatory scheme and systematic risk. For the impact of incentive schemes, they find that low powered ones imply average betas around 0.31 , intermediate 0.60 and high powered 0.71 . A high-powered incentive scheme can be characterized by few regulatory interventions (apart from setting the frame).

${ }^{5}$ She finds that price-cap regulation leads to higher systematic risk than incentive regulation or no regulation. The interesting comparison to rate-of-return regulation is unfortunately not discussed.

${ }^{6}$ Cf. Evans and Guthrie (2005) for a discussion of the link between different concepts for the regulatory asset base and the existence of specific risk due to demand fluctuations when investments are irreversible and Schober et al. (2011) for an analysis of idiosyncratic risks due to the network structure.

7 These points are one major criticism towards empirically-focused models namely the lack of explanatory theory. The results may for instance be explained by regulatory interventions. Regulation authorities can be suspected to investigate bigger firms more intensely than smaller firms. Nwaeze (2000) observes that the increase of risk related to regulatory events is higher for bigger firms.
} 
identified a positive relationship between the book-to-market-ratio of equity value and the required return. This means that firms with a relatively low market value of equity suffer of a distress risk due to poor earnings prospects and thus have higher costs of equity.

\section{Regulators' Approach to Risk and the Cost of Equity}

The overview on empirical research in the previous section has provided ample evidence that methodological choices have a considerable impact on the computed costs of capital. Therefore it is now interesting to investigate to what extent the various methodological choices are reflected in regulatory practice.

Over the past decade, many European regulation authorities have derived equity returns to be used when computing the cost of equity. This work offers ample evidence how regulation authorities value the cost of equity which can be interpreted as a proxy for required equity return. So far the question of how regulators set allowed equity return has not been intensely researched. Therefore research has been conducted on more than 20 regulation schemes.

Table 4 summarizes the key findings on the identified regulatory approaches. All values given are nominal return rates (unless regulators set inflation-adjusted real values) in order to adequately capture actual regimes. Besides the numbers, this analysis provides further interesting insights into the regulatory process of defining the adequate return on equity.

Table 4: Regulators' approaches to network cost of capital

\begin{tabular}{|c|c|c|c|c|c|c|c|c|c|c|c|c|c|c|}
\hline Country & Refer & Period & $\boldsymbol{\beta}_{\mathrm{e}}$ & $\boldsymbol{\beta}_{\mathbf{a}}$ & Value & $\mathbf{r}_{\mathrm{m}}-\mathbf{r}_{\mathrm{f}}$ & $\mathbf{r}_{\mathbf{f}}$ & $\begin{array}{l}\mathbf{r}_{\mathbf{e}} \\
\text { post }\end{array}$ & $\begin{array}{l}\mathbf{r}_{\mathbf{e}} \\
\text { pre }\end{array}$ & & $\begin{array}{l}\mathbf{r}_{\mathbf{d}} \\
\text { pre }\end{array}$ & $\begin{array}{l}\text { WACC } \\
\text { pre }\end{array}$ & $\begin{array}{l}\text { WACC } \\
\text { post }\end{array}$ & $\begin{array}{l}\text { WACC } \\
\text { vanilla }\end{array}$ \\
\hline Australia & R (2009) & 2009-14 & 0.80 & 0.39 & Nom. & $6.5 \%$ & $5.7 \%$ & $10.9 \%$ & $15.5 \%$ & 0.60 & $7.5 \%$ & $10.7 \%$ & $7.5 \%$ & $8.8 \%$ \\
\hline Austria & -Control (2009) & $2010-13$ & 0.69 & 0.33 & Nom. & $5.0 \%$ & $4.2 \%$ & $7.6 \%$ & $10.1 \%$ & 0.60 & $5.0 \%$ & $7.0 \%$ & $5.3 \%$ & $6.0 \%$ \\
\hline Belgium & CREG (2008) & 2007 & 0.88 & 0.38 & Nom. & $2.5 \%$ & $3.8 \%$ & $7.2 \%$ & $11.0 \%$ & 0.67 & $4.5 \%$ & $6.6 \%$ & $4.4 \%$ & $5.4 \%$ \\
\hline Czech Rep. & ERO (2009) & 2010-14 & 0.54 & 0.35 & Nom. & $6.4 \%$ & $4.6 \%$ & $8.0 \%$ & $9.9 \%$ & 0.40 & $4.9 \%$ & $7.9 \%$ & $6.4 \%$ & $6.8 \%$ \\
\hline Estonia & ECA (2010) & 2010 & 0.74 & 0.34 & Nom. & $5.0 \%$ & $5.5 \%$ & $9.2 \%$ & $9.2 \%$ & 0.50 & $6.3 \%$ & $7.8 \%$ & $7.8 \%$ & $7.8 \%$ \\
\hline France & CRE (2009) & 2010 & 0.66 & 0.33 & Nom. & $4.5 \%$ & $4.2 \%$ & $7.2 \%$ & $10.9 \%$ & 0.60 & $4.8 \%$ & $7.3 \%$ & $4.8 \%$ & $5.7 \%$ \\
\hline Finland & EMA (2007) & 2008-11 & 0.40 & 0.30 & Nom. & $5.0 \%$ & $3.8 \%$ & $6.0 \%$ & $7.4 \%$ & 0.30 & $4.4 \%$ & $6.5 \%$ & $5.2 \%$ & $5.5 \%$ \\
\hline Germany & BNetzA (2008) & 2009-13 & 0.79 & 0.40 & Nom. & $4.6 \%$ & $4.2 \%$ & $7.8 \%$ & $9.3 \%$ & 0.60 & & & & \\
\hline Hungary & HEO (2009) & $2009-12$ & 0.43 & 0.26 & Real & $5.9 \%$ & $4.6 \%$ & $7.1 \%$ & $8.9 \%$ & 0.57 & $6.4 \%$ & $7.5 \%$ & $6.0 \%$ & $6.7 \%$ \\
\hline Ireland & CER (2005) & 2006-10 & 0.80 & 0.40 & Real & $5.3 \%$ & $2.4 \%$ & $6.6 \%$ & 0.08 & 0.50 & $3.7 \%$ & $5.6 \%$ & $4.9 \%$ & $5.2 \%$ \\
\hline Italy & AEEG (2008) & 2008-11 & 0.60 & 0.33 & Nom. & $4.0 \%$ & $4.5 \%$ & $6.9 \%$ & $8.6 \%$ & 0.50 & $5.4 \%$ & $7.0 \%$ & $5.6 \%$ & $6.1 \%$ \\
\hline Kosovo & ERO (2006) & 2006-10 & 0.90 & 0.41 & Real & $5.5 \%$ & $5.5 \%$ & $11.8 \%$ & $14.7 \%$ & 0.60 & $8.2 \%$ & $10.8 \%$ & $8.6 \%$ & $9.6 \%$ \\
\hline Luxembourg & ILR (2008) & 2009 & 0.80 & 0.39 & Nom. & $4.6 \%$ & $4.4 \%$ & $8.0 \%$ & $11.5 \%$ & 0.60 & $5.2 \%$ & $7.7 \%$ & $5.4 \%$ & $6.3 \%$ \\
\hline Netherlands & Oxera (2009) & 2010- & 0.83 & 0.30 & Nom. & $5.0 \%$ & $4.1 \%$ & $8.2 \%$ & $11.7 \%$ & 0.60 & $5.3 \%$ & $7.9 \%$ & $5.5 \%$ & $6.5 \%$ \\
\hline New Zealand & Co. Com. (2010) & 2009-13 & 0.75 & 0.35 & Nom. & $7.5 \%$ & $5.4 \%$ & $9.4 \%$ & $13.4 \%$ & 0.60 & $7.4 \%$ & $9.8 \%$ & $6.8 \%$ & $8.2 \%$ \\
\hline Norway & Mail document & 2007-11 & 0.88 & 0.35 & Nom. & $4.0 \%$ & $3.3 \%$ & $6.8 \%$ & $9.4 \%$ & 0.60 & & & & \\
\hline Portugal & Mail document & 2009-12 & 0.91 & 0.61 & Nom. & $4.0 \%$ & $4.4 \%$ & $8.0 \%$ & $10.9 \%$ & 0.61 & $5.1 \%$ & $7.4 \%$ & $5.4 \%$ & $6.2 \%$ \\
\hline Spain & CNE (2007) & 2009- & 0.57 & 0.35 & Nom. & $5.5 \%$ & $4.4 \%$ & $7.6 \%$ & $10.8 \%$ & 0.37 & $5.1 \%$ & $8.7 \%$ & $6.1 \%$ & $6.7 \%$ \\
\hline Sweden & Icecapital (2009) & 2008-11 & 0.63 & 0.48 & Nom. & $4.9 \%$ & $3.8 \%$ & $7.9 \%$ & $11.0 \%$ & 0.29 & $4.8 \%$ & $9.2 \%$ & $6.6 \%$ & $7.0 \%$ \\
\hline Switzerland & UVEK (2010) & 2010 & 0.88 & 0.35 & Nom. & $5.0 \%$ & $3.0 \%$ & $7.4 \%$ & $9.3 \%$ & 0.60 & $2.5 \%$ & $5.2 \%$ & $4.2 \%$ & $4.5 \%$ \\
\hline UK & OFGEM (2009) & 2010-15 & 0.97 & 0.34 & Real & $4.0 \%$ & $2.8 \%$ & $6.7 \%$ & $9.3 \%$ & 0.65 & $3.6 \%$ & $5.6 \%$ & $4.0 \%$ & $4.7 \%$ \\
\hline
\end{tabular}

Bold printed values are indicated as major results in the sources. Data were mostly directly provided by regulation authorities, indications for sources are given in Appendix A. Some further remarks are necessary: In Estonia, pre- and post-tax values are equal due to a special tax regime. Ireland values were based upon the approach for transmission operators. Kosovo considers an additional size premium of $1.5 \%$. New Zealand uses a special form of the CAPM, the Lally-CAPM in which the market risk premium is corrected for taxes.

The numerical results differ significantly, the risk premium varying between 3\% (Belgium) and $7.5 \%$ (New Zealand) and the asset beta ranging from 0.26 (Hungary) up to 0.61 (Portugal). These market risk premia and betas all reflect the regulation authorities' expectations for a comparable time span (2007 up to 2014) rather than concrete empirical findings. Therefore some aggregated results are presented in Table 5. 
Table 5: Summary of results, average value per regional subsample and corresponding standard deviation (in parentheses)

\begin{tabular}{lcccc}
\hline \hline Subsample & $\boldsymbol{\beta}_{\mathbf{a}}$ & $\mathbf{r}_{\mathbf{m}}-\mathbf{r}_{\mathbf{f}}$ & Gearing & $\mathbf{r}_{\mathbf{u}}-\mathbf{r}_{\mathbf{f}}$ \\
\hline \hline Western Europe & $0.35(0.03)$ & $4.5 \%(0.5 \%)$ & $0.57(0.08)$ & $3.6 \%(0.6 \%)$ \\
Eastern Europe & $0.34(0.06)$ & $5.7 \%(2.0 \%)$ & $0.52(0.09)$ & $4.0 \%(1.6 \%)$ \\
Scandinavia & $0.38(0.09)$ & $4.6 \%(1.0 \%)$ & $0.40(0.18)$ & $3.3 \%(1.0 \%)$ \\
Austr. \& New Zeal. & $0.37(0.03)$ & $7.0 \%(1.1 \%)$ & $0.60(0.0)$ & $4.6 \%(0.8 \%)$ \\
World & $0.37(0.07)$ & $5.0 \%(1.1 \%)$ & $0.54(0.11)$ & $3.7 \%(0.9 \%)$ \\
\hline
\end{tabular}

Considering all approaches analyzed in the context of this study, some patterns become visible. Firstly, the average asset beta corresponds to 0.37 with a standard deviation of 0.07 (cf. Table 5). Secondly, Western Europe regulators use homogenous approaches to set the network operation equity premium: The standard deviation amounts to only $0.6 \%$ for the 13 Western European countries. Thirdly, regulators often use lower values for the market risk premium than the values historically observed. Brigham et al. (1985) and Dimson et al. (2003) claim that expected risk premiums should be used rather than historical data, the latter estimating a forward-looking arithmetic mean risk premium at about $5 \%$ for a world series. The arithmetic mean equity risk premium for network operators corresponds to $5.0 \%$ with a standard deviation $1.1 \%$. With regard to the weighted average cost of capital, approaches to gearing, i.e. the ratios of debt to total capital, vary significantly between countries: the range is 0.3 to 0.7 with an average of 0.54 and a standard deviation of 0.11 . The Western European group again is relatively homogenous with an average of 0.57 and a standard deviation of 0.08 .

Concerning methodological choices, five aspects are worth noticing. Firstly and foremost, all regulators considered use single-moment CAPMs. The only regulation authority that considered a DGM to validate CAPM-results was OFGEM. The impact of this methodological choice will be investigated in detail in the following section. Secondly, only Kosovo adopted a size risk premium of 1.3\%, but not based on the Fama and French (1995) approach. The results are thus comparable to the results of Besley and Bolton (1994) who find that US regulation authorities have not considered the size effect in rate setting. Thirdly, practically all regulators that computed 'proper' betas in the process considered data from integrated utilities that include activities such as generation and wholesale. Fourthly, many regulators computed separate betas for electricity and gas, which is probably due to the existence of large (vertically integrated) companies with a focus on either electricity or gas such as Scottish Power, Endesa, Gaz de France etc., which are listed in stock exchanges. Fifthly, many regulators modify beta values after a regulation period has been terminated. As such, they are in line with the proposition of section 2 that regulatory events modify the systematic risk.

\section{Comparison of Valuation Approaches for Network Operators}

The aim of this section is to investigate whether the choice of regulators to use only CAPM is well-founded. Therefore besides the classic CAPM, a TFM (comparable to Fama and French) and an Arbitrage Pricing Model with pre-specified factors based on Chen, Ross and Roll (1986) are fitted to a portfolio of more than 20 network operators. ${ }^{8}$ As shown in the previous sections, the calculus of network operators' capital costs should not be based on the stock data of integrated utilities companies. Unfortunately most network operators worldwide, even with unbundling requirements in place for instance in the European Union, are part of conglomerates or even nationalized and thus not listed on stock exchanges. This directly leads to a relative heterogeneous set of network operators that have to be used to compute marketbased capital costs, but it is the only market-data based driven approach to identify risk premia for network operation.

\footnotetext{
${ }^{8}$ The models will be abbreviated with FF-TFM and CRR-APT in the following chapter. The following network operators were included: APA Group, DUET Group, Envestra, Spark Infrastructure, SP AusNet (all Australia); Elia, Snam Rete Gas, Terna, Enagas, Red Electrica, National Grid (all Europe); AGL Resources, Atmos Energy, ITC Holding, Kinder Morgen Energy P., Jersey Resources Nicor Inc, Northwest Natural Gas, Piedmont Natural Gas, TC Pipelines, WGL Holding Inc (all US)
} 


\section{Results for the CAPM}

The first part of the analysis consists in computing CAPM betas via a time series regression using monthly data from 2000 up to 2010 and equally weighted portfolios. ${ }^{9}$ The network operators are regrouped into the Portfolios 'US NetOp', 'Europe NetOp' and 'Australia NetOp', all network operators from these three portfolios being represented in 'World NetOp'. ${ }^{10}$ The Dow Jones Utilities, the Euro Stoxx Utilities and ASX 200 Energy are included in the analysis to represent benchmark portfolios including mostly integrated utilities companies. Overall regression quality is average to low with regression coefficients mostly below 0.3 .

Table 6: CAPM factors

\begin{tabular}{lccc}
\hline \hline Portfolio & $\boldsymbol{\beta}_{\mathbf{e}}$ & t-statistic & $\mathbf{R}^{2}$ \\
\hline \hline Australia - NetOp & 0.40 & $5.2^{* * *}$ & 0.19 \\
Australia - Integr & 0.51 & $4.4^{* * *}$ & 0.14 \\
Europe - NetOp & 0.30 & $5.1^{* * *}$ & 0.18 \\
Europe - Integr & 0.58 & $6.2^{* * *}$ & 0.24 \\
US - NetOp & 0.39 & $5.3^{* * *}$ & 0.19 \\
US - Integr & 0.76 & $6.3^{* * *}$ & 0.25 \\
World - NetOp & 0.34 & $7.4^{* * *}$ & 0.32 \\
\hline
\end{tabular}

${ }^{* * * *}$ significant at $99 \%,{ }^{* *}$ at $95 \%$ and ${ }^{*}$ at $90 \%$

All betas are significantly different from zero with t-statistics above 4 . Further tests were conducted in order to check if the activity in the value chain (transmission or distribution) and the product (electricity, gas) matters concerning beta. The results showed only minor differences, none of them significant. The different risk profiles of integrated utilities and network operators are obvious and significant, integrated companies being characterized by higher systematic risk.

\section{Results for the FF-TFM}

In the second part of the analysis, betas for a TFM are computed with a similar parameterization as the CAPM (portfolios, monthly data, etc.). SMB data are derived from monthly return differences between MSCI All-World Big Cap and MSCI All-World Small Cap (World), Dow Jones Industrial and S\&P 600 Small Cap (US), Euro Stoxx 50 and Euro Stoxx Small (Europe), S\&P/ASX 20 and S\&P/ASX Small Ordinaries (Australia). HML data published by French (2010) with regards to the US, Europe (including UK) and Australia were used. ${ }^{1}$

\footnotetext{
${ }^{9}$ The approach of equally-weighting the portfolio elements is often used in empirical work such as Blume (1975) and Banz (1981). This is in line with Frankfurter and Vertes (1990) who find that value-weighted portfolios are biased downwards in risk, even for large portfolios

${ }^{10}$ Consequently, Transener is excluded from further analysis. The corresponding market indices used to compute beta are Dow Jones Industrial (US), Euro Stoxx 50 (Europe), S\&P/ASX 200 (Australia) and the FTSE All World Index. Financial data were extracted from Reuters. 10 years of monthly returns from July 2000 until June 2010 are represented in the analysis. As some of the companies were not listed in 2000, the starting portfolios in 2000 represent only two stocks for the Australian and two stocks for the European portfolio. Enagas and Snam Rete gas are added to the European portfolio beginning 2001. The risk free interest rate is calculated based on one-month T-Bill (US), Euribor one-month (Europe) and Federal Reserve Bank accepted bills 30 days (Australia). A fictive World risk free rate is computed with weighting US, Europe and Australia data with market capitalizations.

${ }^{11}$ In the classic Fama and French (1997) paper, SMB is derived separating NYSE, AMEX and NASDAQ assets in 6 portfolios considering size (small or big) and book-to-market (low, medium, high). SMB is the calculated as difference between the average of the big and small portfolios. The Index-based approach used in this paper is pragmatic, as the building of the portfolios and the value updating is handled by a financial intermediary. The results of both approaches (Index-based, portfolio-based) were tested with the US-data set and found to provide similar results. The missing years in the data set of Kenneth E. French (2008-2010 for Europe and Australia) were completed with US data.
} 
Table 7: TFM factors

\begin{tabular}{lccccccc}
\hline \hline Portfolio & $\boldsymbol{\beta}_{\mathbf{e}}$ & $\mathbf{t}$-stat & $\mathbf{s}_{\mathbf{e}}$ & $\mathbf{t}$-stat & $\mathbf{h}_{\mathbf{e}}$ & $\mathbf{t}$-stat & $\mathbf{R}^{2}$ \\
\hline \hline Australia - NetOp & 0.45 & $5.5^{* * *}$ & 0.12 & $1.8^{*}$ & -0.02 & -0.3 & 0.20 \\
Australia - Integr & 0.76 & $7.5^{* * *}$ & 0.62 & $7.5^{* * *}$ & -0.29 & $-2.6^{* *}$ & 0.42 \\
Europe - NetOp & 0.32 & $5.4^{* * *}$ & 0.14 & $2.3^{* *}$ & -0.04 & -0.5 & 0.23 \\
Europe - Integr & 0.52 & $5.6^{* * *}$ & 0.09 & 0.9 & 0.40 & $2.9^{* * *}$ & 0.32 \\
US - NetOp & 0.30 & $4.4^{* * *}$ & 0.34 & $4.0^{* * *}$ & 0.04 & 0.6 & 0.30 \\
US - Integr & 0.73 & $5.9^{* * *}$ & -0.09 & -0.6 & 0.25 & $2.2^{* *}$ & 0.27 \\
World - NetOp & 0.27 & $5.9^{* * *}$ & 0.18 & $2.1^{* *}$ & 0.12 & $1.8^{*}$ & 0.37 \\
\hline
\end{tabular}

${ }^{* * *}$ significant at $99 \%,{ }^{* *}$ at $95 \%$ and ${ }^{*}$ at $90 \%$

Market return is the most statistically significant factor. Interestingly, HML is more relevant for integrated companies (higher sensitivities, higher t-statistics) than for network operators while the effect is the exact opposite regarding SMB. For six out of the seven time series analyzed, only one additional factor is significant (at a 95\% level), while only for the World series for network operators all factors are found to be relevant. This signifies clearly that the use of additional factors improves the explanatory power of the model capturing also more variance. The sensitivity to SMB is positive for network operators which is in line with expectations but contrasts the results of Fama and French (1997) who found negative sensitivities for the utilities industry. The results for the portfolio 'US-Integr' are in line with FF, but the SMB factor is not significant. Another interesting result is the negative sign of $h_{i}$ for 'Australia-Integr' which is significant. In the classic FF-paper, negative signs for $h_{i}$ are found among others for the sectors 'drugs', 'medical equipment', 'electronic equipment' and 'retail'. A negative sensitivity may be interpreted that assets of these sectors may serve as hedge if the risk premium for being a value stock increases.

\section{Results for the CRR-APT}

The third part of the analysis consists of the computation of an APT. There are two basic approaches for constructing APT-models, explanatory factor analysis (directly leading to factors and factor loadings, but without theoretical background about the nature of the factors) and the pre-specification of factors, followed by the computation of the factor loadings. The second approach is used here, as from a practitioner's point of view it is more intuitive to have an explicit understanding of the factors influencing the required return on equity. Based on the evidence presented in Chen, Ross and Roll (1986), a seminal paper in arbitrage pricing with pre-specified factors, the following explaining factors are included in the model: ${ }^{12}$

Table 8: APT factors

\begin{tabular}{|c|c|c|c|}
\hline Risk & Significance & Measurement & Data source \\
\hline Interest rate & Time preference & $\begin{array}{l}\text { UTS }(\mathrm{t})=\text { Return ( } 10 \text { y gov. bond, } \mathrm{t}) \\
\text { - Return (1 month treasury bill, } \mathrm{t}-1)\end{array}$ & $\begin{array}{l}\text { US Federal Reserve, ECB, } \\
\text { Reserve Bank of Australia }\end{array}$ \\
\hline Confidence & $\begin{array}{l}\text { Higher yields signify } \\
\text { increasing risk aversion }\end{array}$ & $\begin{array}{l}\text { URP(t) = Return (10 y gov. bond, t) } \\
\text { - Return (BAA-securities Moody's, t) }\end{array}$ & US Federal Reserve \\
\hline $\begin{array}{l}\text { Unexpected } \\
\text { inflation }\end{array}$ & $\begin{array}{l}\text { Impact depending on } \\
\text { business }\end{array}$ & $\begin{array}{l}\text { US: UI(t) = CPI(t)/CPI(t-1) - Expected inflation (t) } \\
\text { Australia: No monthly inflation data available } \\
\text { Europe: No expectations available }\end{array}$ & $\begin{array}{l}\text { FED of Minneapolis, University of } \\
\text { Michigan Inflation Expectation }\end{array}$ \\
\hline $\begin{array}{l}\text { Business } \\
\text { cycle }\end{array}$ & $\begin{array}{l}\text { Impact depending on } \\
\text { business }\end{array}$ & $\begin{array}{l}\mathrm{MP}(\mathrm{t}) \text { = Growth rate of industrial production vs. last } \\
\text { month (t) }\end{array}$ & OECD monthly production data \\
\hline $\begin{array}{l}\text { Market } \\
\text { timing }\end{array}$ & $\begin{array}{l}\text { Effects not captured by the } \\
\text { macroeconomic factors }\end{array}$ & $\begin{array}{l}\text { MI }(t)=\text { Residual of indices used previously, part that } \\
\text { is not explained by the four factors presented }\end{array}$ & Dow Jones, Euro Stoxx, ASX/S\&P \\
\hline
\end{tabular}

The sensitivities of network operators asset returns to the macroeconomic factors are identified using a multiple linear regression. This part is indispensable for the analysis, as the

\footnotetext{
${ }^{12}$ The CRR factors were used in an important number of other papers such as Bower et al. (1984), Burmeister and Wall (1986), Berry et al. (1988), Hamao (1988), Burmeister et al. (2003), Kaneko and Lee (1995) and Rjoub et al. (2009). A slight adaptation of the model, presented in Burmeister et al. (2003) was used. Consequently, market return is included as to capture all effects not accounted for by the other factors.
} 
influence of the factors and their significance are the baseline for comparison to the other models.

Table 9: APT results

\begin{tabular}{lccccccccccc}
\hline \hline Portfolio & $\boldsymbol{\beta}_{\mathrm{UTS}}$ & $\mathbf{t}$-stat & $\boldsymbol{\beta}_{\mathrm{URP}}$ & $\mathbf{t}$-stat & $\boldsymbol{\beta}_{\mathrm{UI}}$ & t-stat $_{\mathrm{UI}}$ & $\boldsymbol{\beta}_{\mathrm{MP}}$ & $\mathbf{t}_{\text {-stat }}$ & $\boldsymbol{\beta}_{\mathrm{MI}}$ & t-stat $_{\mathrm{MI}}$ & $\mathbf{R}^{2}$ \\
\hline \hline Australia - NetOp & 0.46 & 1.25 & -0.10 & -0.31 & & & 0.74 & 1.31 & 0.36 & $4.53^{*}$ & 0.19 \\
Australia - Integr & 0.15 & 0.28 & -1.35 & $-2.82^{*}$ & & & 0.57 & 0.69 & 0.44 & $3.82^{*}$ & 0.20 \\
Europe - NetOp & 0.59 & $2.15^{* *}$ & -1.16 & $-2.88^{*}$ & & & -0.18 & -0.66 & 0.27 & $4.59^{*}$ & 0.24 \\
Europe - Integr & 0.60 & 1.35 & -1.35 & $-2.05^{* *}$ & & & 0.53 & 1.18 & 0.51 & $5.20^{*}$ & 0.27 \\
US - NetOp & 0.21 & 1.06 & -0.74 & $-2.29^{* *}$ & -0.06 & -0.09 & -0.59 & -1.59 & 0.35 & $4.88^{*}$ & 0.21 \\
US - Integr & 0.11 & 0.34 & -1.32 & $-2.41^{* *}$ & -0.33 & -0.28 & 0.19 & 0.30 & 0.69 & $5.59^{*}$ & 0.27 \\
World - NetOp & 0.23 & 1.30 & -0.85 & $-3.92^{*}$ & & & 0.00 & -0.01 & 0.28 & $6.13^{*}$ & 0.32 \\
\hline
\end{tabular}

${ }^{* * *}$ significant at $99 \%{ }^{* *}$ at $95 \%$ and ${ }^{*}$ at $90 \%$

The explanatory power is in line with Berry et al. (1988) or Elton et al. (1994) who both find that the macroeconomic variables explain roughly one quarter of the indices' variation. Aside from market timing risk, the default risk premium is a significant factor in all portfolios (with the exception of Australian network operators). Betas for the risk premium URP are negative indicating that in the case of more risk averse investors, utilities will profit by lower required equity returns. Unexpected inflation (in the US) and monthly production have no significant explanatory power.

\section{Comparison of the Quality of the Models}

An overview of the results obtained is presented in Table 10Fehler! Verweisquelle konnte nicht gefunden werden.. TFM mostly leads to a considerably higher $R^{2}$ than the CAPM. APT is in most cases superior to the CAPM but only once has a slightly higher $R^{2}$ than the TFM. This may be due to the fact that the pre-specified factors do not work very well, either because they do not capture additional risks or due to measurement issues. An alternative might be to use factor analysis to generate factors that do not have an obvious economic interpretation. But given the reality of regulatory hearings it appears to be difficult to implement this methodology. The aim of this section has been to show whether alternatives to the CAPM may work well in the context of setting the cost of capital for a network operators. The TFM does well, the APT rather not.

Table 10: Comparison of different approaches

\begin{tabular}{|c|c|c|c|c|c|c|c|c|c|c|c|c|}
\hline & \multirow{2}{*}{\multicolumn{3}{|c|}{ 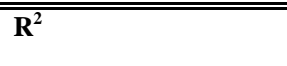 }} & \multicolumn{9}{|c|}{ Jumber of significant factors } \\
\hline & & & & $90 \%$ & & & $95 \%$ & & & $99 \%$ & & \\
\hline & $C A P M$ & TFM & APT & CAPM & TFM & $A P T$ & CAPM & TFM & $A P T$ & CAPM & TFM & $A P T$ \\
\hline Australia - NetOp & 0.19 & 0.20 & 0.19 & 1 & 2 & 1 & 1 & 1 & 1 & 1 & 1 & 1 \\
\hline Australia - Integr & 0.14 & 0.42 & 0.20 & 1 & 3 & 2 & 1 & 3 & 2 & 1 & 2 & 3 \\
\hline Europe - NetOp & 0.18 & 0.23 & 0.24 & 1 & 2 & 3 & 1 & 2 & 3 & 1 & 1 & 2 \\
\hline Europe - Integr & 0.24 & 0.32 & 0.27 & 1 & 2 & 2 & 1 & 2 & 2 & 1 & 2 & 1 \\
\hline US - NetOp & 0.19 & 0.30 & 0.21 & 1 & 2 & 2 & 1 & 2 & 2 & 1 & 2 & 1 \\
\hline US - Integr & 0.25 & 0.27 & 0.27 & 1 & 2 & 2 & 1 & 2 & 2 & 1 & 1 & 1 \\
\hline World - NetOp & 0.32 & 0.37 & 0.32 & 1 & 3 & 2 & 1 & 2 & 2 & 1 & 1 & 2 \\
\hline
\end{tabular}

But one has to bear in mind that the use of additional factors leads to additional sources of uncertainty in the equation, namely the stability of betas and the level of risk premium. Beta stability is always a problem, if the considered time period is relatively short. Therefore, the 10-year period was separated in five 2-year periods and the TFM-calculations were reproduced. We found that stability of $s_{e}$ (measured by the standard deviation of the five periods, normalized by its mean) was comparable to $\beta_{e}$ for European and US network operators and Australian vertically integrated utilities. The stability of $s_{e}$ was comparable to $\beta_{e}$ US integrated utilities. A regulator might thus use these comparably stable sensitivities if the according risk premiums are robust. Therefore, in the following section, risk premiums are derived using the alternative model specifications. 


\section{Estimation of Risk Premiums}

The estimation of risk premiums for each model is based on two major inputs, the sensitivities computed and the risk premiums for each factor. Dimson et al. (2003) present market risk premiums over a time span from 1900 until 2002. Two facts stand out: The high standard deviations (generally larger than 15\%) and the difference of results obtained when using geometric as compared to arithmetic means (at least 1.3\%, sometimes up to 5.5\%). With regard to the Fama and French factors, SMB and HML were computed based on a time span from 1925 until 2009 based on the French (2010) data, the uncertainty being comparable.

Table 11: TFM factor premiums

\begin{tabular}{lccc}
\hline \hline Portfolio & $\mathbf{r}_{\mathrm{e}}-\mathbf{r}_{\mathbf{f}}$ & SMB & HML \\
\hline \hline Geometric mean & $5.9 \%$ & $2.9 \%$ & $3.3 \%$ \\
Arithmetic mean & $8.1 \%$ & $3.8 \%$ & $4.4 \%$ \\
Standard deviation & $20.8 \%$ & $14.3 \%$ & $14.3 \%$ \\
\hline
\end{tabular}

The subject of risk premiums is even vaguer when one gathers APT values. Table 11 summarizes average risk premiums published in different research papers. The important differences between results are obvious, not only regarding the level of risk prices but even their signs, sometimes being positive, sometimes negative. ${ }^{13}$ The problem becomes obvious comparing the results of Chen et al. (1986) with Shanken and Weinstein (2006), which are computed using the same data set but slightly different methodologies regarding portfolio constructing rules. A regulation authority or the management of a network operator will be confronted with an unsolvable task of setting the adequate risk premium. An own analysis using the two-stage approach of Fama and MacBeth (1973) was conducted with data from all companies listed in Dow Jones Industrial Average, Euro Stoxx 50 and S\&P/ASX 50. With data for the period 2000-2010, no significant results could be computed.

Table 12: APT risk factor prices

\begin{tabular}{|c|c|c|c|c|c|c|}
\hline Author & Data & UTS & URP & UI & MP & MI \\
\hline Chen et al. (1986) & 1958-1984 & $-6.6 \%$ & $9.5 \%$ & $-0.9 \%$ & $16.0 \%$ & $4.5 \%$ \\
\hline Berry et al. (1988) & 1972-1982 & $12.0 \%$ & $5.3 \%$ & $-0.5 \%$ & $1.8 \%$ & $6.1 \%$ \\
\hline Elton et al. (1994) & 1978-1990 & $5.8 \%$ & $4.6 \%$ & $-1.0 \%$ & $3.8 \%$ & $4.6 \%$ \\
\hline Kaneko and Lee (1995) & 1975-1993 & $3.3 \%$ & $0.5 \%$ & & $-1.5 \%$ & $8.3 \%$ \\
\hline Burmeister et al. (2003) & Not indicated & $-0.7 \%$ & $2.6 \%$ & $-4.3 \%$ & $1.5 \%$ & $3.6 \%$ \\
\hline Shanken and Weinstein (2006) & 1958-1984 & & $14.3 \%$ & $-1.2 \%$ & $2.8 \%$ & $1.1 \%$ \\
\hline
\end{tabular}

Sources: Chen et al. (1986), means table 4. Kaneko and Lee (1995), table 1. Inflation results are not presented here due to different definition with mean value different from zero. Shanken and Weinstein (2006), table 1, unrestricted values with n=20 and five-year prior betas.

To compute some exemplary results, the values published in Burmeister et al. (2003) are used. These values have been notably reproduced and popularized through textbooks such as Brealey et al. (2007), Pratt and Grabowski (2008) and Elton et al. (2009). Thereby, mean values are considered in calculating risk premiums. The results of risk premiums calculated with CAPM, TFM and APT are summarized in Table 13.

\footnotetext{
${ }^{13}$ This phenomenon appeared for instance in Elton et al. (1994, pp. 56) where the premiums change by factor 10 within 4 years. Another example is Chen et al. (1986, pp. 396) with UTS changing by a factor of about 30 from one 10 years period to another. Poon and Taylor (1991) indicate some problems in their work with APT, sometimes factors are priced, other times not. Martikainen et al. (1991) summarize in an application to Finnish data that it is difficult to find any stable economic interpretation from the pre-specified macro-economic factors.
} 
Table 13: Comparison of risk premiums $\mathrm{r}_{\mathrm{e}}-\mathrm{r}_{\mathrm{f}}$

\begin{tabular}{lcccc}
\hline \hline Portfolio & CAPM & TFM & APT (Burm.) & APT (means) \\
\hline \hline Australia - NetOp & $2.7 \%$ & $3.3 \%$ & $3.0 \%$ & $6.4 \%$ \\
Australia - Integr & $3.5 \%$ & $6.0 \%$ & $0.2 \%$ & $-2.2 \%$ \\
Europe - NetOp & $1.2 \%$ & $1.6 \%$ & $-2.6 \%$ & $-5.5 \%$ \\
Europe - Integr & $2.4 \%$ & $3.7 \%$ & $-1.1 \%$ & $-2.3 \%$ \\
US - NetOp & $2.1 \%$ & $2.7 \%$ & $-0.8 \%$ & $-4.8 \%$ \\
US - Integr & $4.0 \%$ & $4.4 \%$ & $1.8 \%$ & $-2.8 \%$ \\
World - NetOp & $1.5 \%$ & $2.1 \%$ & $-1.2 \%$ & $-3.5 \%$ \\
\hline
\end{tabular}

Consistent with literature, important differences in valuation are visible. The negative risk premium in the APT models is mostly due to an important sensitivity of all portfolios towards URP. This means that required equity return for network operators decreases if the default risk premium increases. Interestingly, the effect is solely due to the development of the risky bonds, the development of the long term government bond being insignificant. The sensitivities to URP are not abnormal, Berry et al. (1996) reporting similar values for the utility industry. To get a better understanding of this relationship, more long term data is required.

Summarizing, additional factors improve results. From a regulation authority's point of view, the use of a TFM does not add much complexity to the process of estimation of cost of capital and is especially useful due to the significance and the robustness of SMB. The use of APT is more complex, as one has to either overcome difficulties in the setting of risk prices or rely on the factor analysis approach, which will be difficult to explain to the stakeholders of regulation. The problem of risk prices is less severe for TFM as published long term data (at least for the US) is available and risk prices are much less volatile over time.

\section{A Simplified Two-Factor-Model with SMB for Non-listed Firms}

The results of the previous section suggest the additional use of SMB in setting the equity returns for regulated network operators. The identification of $s_{e}$ is based on a portfolio of network operators which may be much bigger than the firms the regulator is setting the equity returns for. A regulator could thus identify required equity return based on the following twofactor-model excluding HML. The question arises if a portfolio of smaller network operators would be characterized by different values of $s_{e}$. If this is the case, the regulator might opt for a choice to set higher levels of $s_{e}$ and thus attribute an additional size premium that smaller operators require to have a sustainable equity return. To analyze, if an important correlation between $s_{e}$ and network size $l_{e}$ (measured in $\mathrm{km}$ of cables, overhead lines, pipelines and tubes) exists, the following relationship has to be significant.

$$
s_{e}=a+b \cdot l_{e}+\varepsilon
$$

If $l_{\text {target }}$ corresponds to the target size, the regulation authority wishes to set equity returns for, and $l_{e}$ represents the average network size, then the following equation for the required equity returns results.

$$
r_{e}-r_{f}=a+\beta_{e}\left(r_{m}-r_{f}\right)+s_{e} S M B+b\left(\bar{l}_{e}-l_{\text {target }}\right) S M B
$$

To identify $b$, three cross sectional regressions have been conducted based on the model described above. As expected, network size $l_{e}$ and the sensitivity to $S M B s_{e}$ are negatively correlated. $R^{2}$ values are at a reasonable level at least for the 10-years perspective. The effect is relatively weak indicating that SMB impact is due to the business activity.

Table 14: Relationship between network size and $\mathrm{s}_{\mathrm{e}}$

\begin{tabular}{lccccc}
\hline \hline Period length & $\alpha$ & t-statistic & $\beta$ & t-statistic & R2 \\
\hline \hline 1 year & 0.3784 & $3.3^{* * *}$ & -0.0006 & -0.5 & 0.02 \\
5 years & 0.2388 & $4.4^{* * *}$ & -0.0008 & -1.1 & 0.06 \\
10 years & 0.2879 & $5.0^{* * *}$ & -0.0010 & $-1.8^{* *}$ & 0.14 \\
${ }^{* * *}$ significant at $99 \%,{ }^{* *}$ at $95 \%$ and $^{*}$ at $90 \%$ & & &
\end{tabular}


The average network operator in our sample is characterized by a network length $\bar{l}_{e}$ of about $65,000 \mathrm{~km}$ and an average $s_{e}$ of 0.18 . For every $10,000 \mathrm{~km}$ of regulatory target size less, $s_{e}$ increases by 0.01 . Having calculated the average risk premium for SMB at a level of $0.6 \%$, if the regulator chose a target size of $5,000 \mathrm{~km}$ than an additional size premium of $0.2 \%$ would result, the total SMB risk premium being $0.8 \%$. This approach shows that the SMB concept can easily be applied to network operators, even if the regulated network operators are significantly smaller than the firms used to evaluate the regulatory parameters.

\section{Conclusions}

This paper has been meant to give a qualitative and quantitative overview of the cost of equity capital for utilities companies with the focus of network operators. The existing literature indicates that there are significant differences in the valuation of the required equity return. The main drivers of these differences are the valuation model, leverage, the position in the value chain and firm size. Some further factors such as the nature of regulation (cost of service, incentive regulation), the branch (electricity, gas) do not turn out to have important impacts. Regulatory events surely influence betas and consequently required equity returns but it depends majorly on the type of these events, if the changes are long-lasting.

Recent approaches of 21 regulation authorities have been thoroughly analyzed to see whether the regulators act according to the results presented in section 2. The results are surprising. None of the regulation authorities, except OFGEM that had additional support by a DGM, uses alternative valuation models to have a second approach besides the CAPM. Many of the regulation authorities include integrated utilities companies in their sample (which is not recommended due to rather different business risks) but differentiate electricity and gas (which is not necessary according to the results provided). Only the regulation authority in Kosovo considers a firm size effect, but without theoretical link to the SMB concept.

With a data set of 20 network operators, CAPM, FF-TFM and CCR-APT models have been built in order to compute required equity returns. If these models would all lead to approximately the same results with a comparable regression quality, then the approach to use solely the CAPM might be appropriate. Yet both multi factor models are found to have more explanatory power than the single factor CAPM, unfortunately at a certain price. The use of more factors leads to a reduction of intuitiveness, stability issues and requires additional assumptions about risk premiums, which could be contested by regulated companies. As for the sensitivities of network operators to additional risks beside market risk, the default risk premium SMB has a very high significance with regard to network operators. Consequently, a consideration in asset pricing seems appropriate and would result in additional equity returns between 0.4 and $0.6 \%$.

As for the use of the default risk premium, more research is necessary to compute long term estimates of the risk premium. The incorporation of the size effect in the computation of the required equity return is straightforward. An intuitive approach has been developed how to determine SMB-based size premiums for regulated network operators that differ in size significantly from the firms used to take into account the sensitivity to the size premium SMB. 


\section{References}

AEEG (2008): Tariffe per l'attivita' di tariffe distribuzione e misure del gas naturale per il terzo periodo regolatoria, Presentation in Milan, 20th of March 2008

AEEG Autorità per l'energia elettrica e il gas (2008): Annual Report to the European Commission on regulatory activies and the state of services in the electricity and gas sectors

AER Australian Energy Regulator (2009): Electricity transmission and distribution network service providers Review of the weighted average cost of capital (WACC) parameters - Final Decision

Ahn, C. M.; Thompson, H. E. (1989): An analysis of some aspects of regulatory risk and the required rate of return for public utilities; Journal of Regulatory Economics (VOL. 1); pp.241-257

Alexander, I,; Mayer, C.; Weeds, H. (December 1996): Regulatory structure and risk and infrastructure firms: an international comparison; World Bank, Policy Research Working Papers (Nr. 1698); pp.1-72

Banz, R. W. (1981): The relationship between return and market value of common stocks; Journal of Financial Economics (VOL. 9); pp.3-18

Besley, S.; Bolton, S. E. (1994): Rate Setting in the Utilities Industry: Does Size Make a Difference?; Financial Review (VOL. 29); pp.521-538

Berry, M.; Burmeister, E.; McElroy, M (1988): Sorting out Risks Using Known APT Factors; Financial Analysts Journal (VOL. 44); pp.29-42

BNetzA Bundesnetzagentur (2008): Beschluss BK4-08-068

Bower, D. H.; Bower, R. S.; Logue, D. E. (1984): Arbitrage Pricing Theory and Utility Stock Returns; The Journal of Finance (VOL. 39); pp.1041-1054

Brealey R. A., Myers. S. C.; Franklin, A. (2007): Principles of Corporate Finance; McGraw-Hill Irvin (9th edition)

Brigham, E.F.; Shome, D.K.; Vinson, S. R. (1985): The Risk Premium Approach to Measuring a Utility's Cost of Equity; Financial Management (VOL. 14); pp.33-45

Buckland, R.; Fraser, P. (2001): Political and Regulatory Risk in Water Utilities: Beta Sensitivity in the United Kingdom; Journal of Business Finance \& Accounting (VOL. 28); pp.877-904

Burmeister, E.; Roll, R.; Ross, S. A. (1994): Using Macroeconomic Factors to Control Portfolio Risk; In: A Practitioner's Guide to Factor Models - The Research Foundation of The Institute of Chartered Financial Analysts; pp.1-27

CER Commission for Energy Regulation (2005): 2006-2010 Transmission Price Control Review: Transmission Asset Owner (TAO) and Transmission System Operator (TSO)

Chen, N. F.; Roll, R.; Ross, S. A. (1986): Economic forces and the stock market; The Journal of Business (VOL. 59); pp.383-403

Clarke, R. G. (1980): The Effect of Fuel Adjustment Clauses on the Systematik Risk and Market Values of Electric Utilities; Journal of Finance (VOL. 35); pp.347-358

CNE (2007): Consulta pública para la revisión de la metodología de estimación del coste de capital para actividades reguladas en el sector energético, Presentation, 13th of December 2007

Commerce Commission (2010): Cost of Capital Straw Person Example - Electricity distribution industry

CRE Commission de Régulation de l'Énergie (2009): Proposition de la Commission de régulation de l'énergie du 26 février 2009 relative aux tarifs d’utilisation des réseaux publics de transport et de distribution d’électricité

CREG Commission de Régulation de l'Electricité et du Gaz (2008): RAPPORT TE 2008 relatif aux 'tarifs du réseau de distribution appliqués par les gestionnaires de réseaux de distribution d'électricité au cours de l'exercice d'exploitation 2008'

Conine, T. E.; Tamarkin, M. (1985): Implications of Skewness in Returns for Utilities' Cost of Equity Capital; Financial Management (VOL. 14); pp.66-71

Cooper, I.; Currie, D. (1999): The Cost of Capital for the UK Water Sector; London Business School, Regulation Initiative Discussion Paper Series (NO. 28); pp.

Cragg, M.; Lehr, W.; Rudkin R. (2001): Assessing the Cost of Capital for a Standalone Transmission Company; The Electricity Journal (VOL. 14); pp.80-88

Dimson, E.; Marsh, P.; Staunton, M (2003): Global Evidence on the Equity Risk Premium; Journal of Applied Corporate Finance (VOL. 15); pp.27-38

Dixit, A. K.; Pindyck, R.S. (1994): Investment under Uncertainty; Princetown University Press, Princeton, New Jersey

Dobbs, I. M. (2008): Setting the Regulatory Allowed Rate of Return Using Simulation and Loss Functions -The Case for Standardising Procedures; Competition and Regulation in Network Industries (VOL. 9); pp.229247 
ECA Estonian Competition Authority (2010): Guidelines for determination of Weighted Average Cost of Capital E-Control (2009): Erläuterungen zur Systemnutzungstarife-Verordnung 2010, SNT-VO 2010

Elton, E.; Gruber, M.J.; Brown, S. J.; Goetzmann, W. N. (2009): Modern Portfolio Theory and Investment Analysis; Wiley, New York (Eight Edition)

Elton, E.; Gruber, M.J.; Mei, J. (1994): Cost of Capital Using Arbitrage Pricing Theory: A Case Study of Nine New York Utilities; Financial Markets, Institutions and Instruments (VOL. 3); pp.46-73

EMA Energy Market Authority (2007): ENERGIMARKNADSVERKET Appendix 1 - Methods for determining the return on electricity distribution network operations during the regulatory period starting on 1 January 2008 and ending on 31 December 2011

ERO Energy Regulatory Office (2009): Final Report of the Energy Regulatory Office on the regulatory methodology for the third regulatory period, including the key parameters of the regulatory formula and pricing in the electricity and gas industries

ERO-KS Energy Regulatory Office (2006): Weighted Average Cost of Capital - Position Paper

Evans, L.T.; Guthrie, G.A. (2005) Risk, price regulation, and irreversible investment; International Journal of Industrial Organization (VOL. 23); pp.109-128

Fama, E. F.; French, K. (1992): The Cross-Section of Expected Stock Returns; The Journal of Finance (VOL. 47); pp.427-465

Fama, E. F.; French, K. (1995): Size and Book-to-Market Factors in Earnings and Returns; The Journal of Finance (VOL. 50); pp.131-155

Fama, E. F.; French, K. (1997): Industry Costs of Equity; Journal of Financial Economics (VOL. 43); pp.153193

Fama, E. F.; French, K. (1998): Value versus Growth: The International Evidence; The Journal of Finance (VOL. 53); pp.1975-1999

Frankfurter, G.; Vertes, P. (1990): Some empirical evidence of bias in random, market-value-weighted portfolios; The Journal of Economics and Business (VOL. 42); pp.213-222

French, K. (2010): http://mba.tuck.dartmouth.edu/pages/faculty/ken.french/data_library.html

Frontier Economics (2008): Ermittlung des Zuschlags zur Abdeckung netzbetriebsspezifischer Wagnisse im Bereich Strom und Gas; Report for Bundesnetzagentur

Gerke, W. (2003): Risikoadjustierte Bestimmung des Kalkulationszinssatzes in der Stromnetzkalkulation Kalkulationsgrundlagen in der Energieversorgung; VDEW (Band 1)

Gray, S.; Officer, B. (12th of November 2004): The Equity Beta of an Electricity Distribution Business ; Draft Report prepared for CitiPower LTD and Powercor Australia Ltd (); pp.

Griffin, J. M. (2002): Are the Fama and French Factors Global or Country Specific?; The Review of Financial Studies (VOL. 15); pp.783-803

Hamao, Y. (1988): An Empirical Examination of the Arbitrage Pricing Theory; Japan and the World Economy (VOL. 1); pp.45-61

Higgins, R. C. (1974): Growth, Dividend Policy and Capital Costs in the Electric Utility Industry; The Journal of Finance (VOL. 29); pp.1189-1201

Icecapital (2009): WACC ÅR 2008, Study for Swedish regulation authority

ILR Institut Luxembourgeois de Régulation (2008): Résultat de la consultation publique se terminant le 16 mai 2008 sur les méthode de détermination des tarifs d'utilisation des réseaux, élaborées sur base de l'article 20(1) de la loi du 1er août 2007 relative à l’organisation du marché de l'électricité

Kaneko, T.; Lee, B.-S. (1995): Relative Importance of Economic Factors in the U.S. and Japanese Stock Markets; Journal of the Japanese and International Economies (VOL. 9); pp.290-307

Kema Consulting (2008): Ermittlung angemessener Kapitalzinssätze für deutsche Strom- und Gasverteilnetze; Report for VKU

Kihm, S. G. (2007): The Proper Role of the Cost-of-Equity Concept in Pragmatic Utility Regulation; The Electricity Journal (VOL. 20); pp.26-34

Knecht, R. (2009): Use of the Fama-French Three-Factor Model by Nevada PUC Staff; For Society of Utility and Regulatory Financial Analysts (SURFA, April 19th 2009)

Lally, M. (2005): The Equity Beta for ETSA Utilities; Report

Lintner, J. (1965): The valuation of risk assets and the selection of risky investments in stock portfolios and capital budgets; Review of Economics and Statistics (VOL. 47); pp.13-37

Litzenberger, R. H.; Rao, C. U. (1971): Estimates of the Marginal Rate of Time Preference and Average Risk Aversion of Investors in Electric Utility Shares: 1960-66; Bell Journal of Economics (VOL. 2); pp.265-277

Markowitz, H. (1952): Portfolio Selection; The Journal of Finance (VOL. 7); pp.77-91

Martikainen, T.; Yli-Olli, P.; Gunasekaran, A. (1991): Incremental significance of pre-specified macroeconomic factors in testing the arbitrage pricing theory: empirical evidence with Finnish data; Applied Financial Economics (VOL. 1); pp.139-147 
McDonald, J. G. (1971): Required Return on Public Utility Equities: A National and Regional Analysis, 19581969 ; Bell Journal of Economics (VOL. 2); pp.503-514

McElroy, M. E.; Burmeister, E. (1988): Arbitrage Pricing Theory as a Restricted Nonlinear Multivariate Regression Model: Iterated Nonlinear Seemingly Unrelated Regression Estimates; Journal of Business \& Economic Statistics (VOL. 6); pp.29-42

Miller, I.; Zhang, J. (2003): Estimating Risk Parameters for Water and Power Utilities in China; Journal of Structured Finance (Winter)

Miller, M. H.; Modigliani, F. (1966): Some Estimates of the Cost of Capital to the Electric Utiliy Industry, 19541957; The American Economic Review (VOL. 56); pp.333-391

Mossin, J. (1966): Equilibrium in the Capital Market; Econometrica (VOL. 34); pp.768-783

Norton, S.W. (1985): Regulation and Systematic Risk: The Case of Electric Utilities; Journal of Law and Economics (VOL. 28); pp.671-686

Nwaeze, E. T. (2000): Deregulation of the Electric Power Industry: The Earnings, Risk, and Return Effects; Journal of Regulatory Economics (VOL. 17); pp.49-67

OFGEM (2009): Electricity Distribution Price Control Review, Final Proposals - Allowed Revenues and Financial Issues

Oxera (2009): Updating the WACC for the Energy Networks - Quantitative Analysis - Prepared for Energiekamer

Peltzman, S. (1976): Toward a More General Theory of Regulation; Journal of Law and Economics (VOL. 19); pp.211-240

Pettway, R. H. (1978): On the Use of $\beta$ in Regulatory Proceedings: An Empirical Examination; Bell Journal of Economics (VOL. 9); pp.239-248

Poon, S.; Taylor S. J. (1991): Macroeconomic forces and the UK stock market; Journal of Business Finance \& Accounting (VOL. 18); pp.619-636

Pratt, S. P.; Grabowski, R. J. (2008): Cost of Capital - Applications and Examples; Wiley, New York (Third Edition)

PwC (2009): Advice on the cost of capital analysis for DPCR5; Report for OFGEM

Rammerstorfer, M. (2009): Risk Acceptance and Regulatory Risk; Competition and Regulation in Network Industries (VOL. 10); pp.235-259

Rjoub, H.; Türsoy, T.; Günsel, N. (2009): The effects of macroeconomic factors on stock returns: Istanbul Stock Market; Studies in Economics and Finance (VOL. 26); pp.36-45

Rocha, K.; Camacho, F.; Bragança, G. (2007): Return on capital of Brazilian electricity distributors: A comparative analysis; Energy Policy (VOL. 35); pp.2526-2537

Ross, S. A. (1976): The Arbitrage Pricing Theory of Capital Asset Pricing; Journal of Economic Theory (VOL. 13); pp.341-360

Schober, D.; Schaeffler, S.; Weber, C. (2011): Implicit Discrimination in Regulation: The Role of Firm-Specific Risk due to Size and Age Distribution of Electricity Networks; Working Paper

Shanken, J.; Weinstein, M. I. (2006): Economic forces and the stock market revisited; Journal of Empirical Finance (VOL. 13); pp.129-144

Sharpe, W. F. (1964): Capital asset prices: A theory of market equilibrium under conditions of risk,; The Journal of Finance (VOL. 19); pp.425-442

Shome, D. K.; Smith, S. D. (1988): An Econometric Analysis of Equity Costs and Risk Premiums in the Electric Utility Industry: 1971-1985; Financial Review (VOL. 23); pp.439-452

Thompson, H.E. (1979): Estimating the Cost of Equity Capital for Electric Utilities: 1958-1976; Bell Journal of Economics (VOL. 10); pp.619-635

UVEK Eidgenössisches Departement für Umwelt, Verkehr, Energie und Kommunikation, Bundesamt für Energie BFE - Abteilung Energiewirtschaft (2010): Erläuterungen zur Änderung von Art. 13 Abs. 3 Bst. b der Stromversorgungs-verordnung (StromVV) und dem neuen Anhang 1

Warner, J. B. (1977): Bankrupty Costs: Some Evidence; The Journal of Finance (VOL. 32); pp.337-347

Wright, S.; Mason, R.; Miles, D. (2003): A Study into Certain Aspects of the Cost of Capital for Regulated Utilities in the UK; OFGEM, Network Policy Papers (Reference number: 08/03)) 